\title{
SEASONAL CHANGES IN NUTRIENT AVAILABILITY FOR SULFUR-AMENDED EVERGLADES SOILS UNDER SUGARCANE
}

\author{
Rongzhong Ye, ${ }^{1}$ Alan L. Wright, ${ }^{2}$ and J. Mabry McCray ${ }^{2}$ \\ ${ }^{1}$ Soil $\mathcal{E}^{2}$ Water Science Department, University of Florida, Gainesville, Florida, USA \\ ${ }^{2}$ Everglades Research $\mathcal{E}$ Education Center, University of Florida, Belle Glade, Florida, USA
}

\begin{abstract}
$\square \quad$ The objective of this study was to evaluate effects of elemental sulfur $(S)$ addition on soil $p H$ and availability of macro- and micronutrients during the sugarcane growing season. Sulfur application

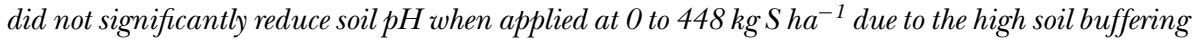
capacity. Water extractable phosphorus $(P)$ and potassium $(K)$ for soils receiving the highest $S$ rate were $188 \%$ and $71 \%$ higher than for unamended soils only at two months after application, indicating a short-term enhancement of macronutrient availability. Soil amended with $448 \mathrm{~kg} \mathrm{Sha}$ contained $134 \%$ more acetic acid-extractable zinc $(\mathrm{Zn})$ than unamended soil, although stimulatory effects did not extend beyond two months. Sugar yield was not affected by $S$ addition, averaging $17 \mathrm{Mg}$ sugar $\mathrm{ha}^{-1}$. The failure of $S$ to enhance nutrient availability throughout the growing season indicates the limited benefit of applying elemental $S$ to reduce $p H$ and increase nutrient availability to sugarcane.
\end{abstract}

Keywords: Everglades Agricultural Area, Histosols, nutrients, sugarcane, sulfur

\section{INTRODUCTION}

The availability of essential elements is known to affect the yield and quality of crops (Heitholt et al., 2002; Parsons et al., 2007). Soils are major sources for plant nutrients; however, their nutrient availability varies during the growing season depending on characteristics such as soil organic matter content, pH, and cation-exchange capacity (Cancela et al., 2002; Strahm and Harrison, 2007). Soil management practices, such as fertilization and amendments, are commonly employed to enhance the nutrient supply and increase crop yields. Nonetheless, the status and behavior of nutrients in soil are difficult to predict (Moral et al., 2002; Moreno-Caselles et al., 2005;

Received 1 October 2009; accepted 30 April 2010.

Address correspondence to Alan L. Wright, Everglades Research \& Education Center, University of Florida, 3200 E. Palm Beach Road, Belle Glade, FL 33430-4702, USA. E-mail: alwr@ifas.ufl.edu 
Herencia et al., 2008). Interactions among nutrients affect their availability to crops (Rice et al., 2006) as an over-abundance of one nutrient may lead to a deficiency of another. For instance, excessive phosphorus $(\mathrm{P})$ fertilization can decrease zinc (Zn) availability due to precipitation (Li et al., 2007). Thus, applying proper amounts of fertilizers or amendments minimizes nutrient imbalances, maximizes crop yields, and improves fertilizer use efficiency.

Soil testing is widely used for evaluating nutrient availability and justifying fertilizer application rates to maximize crop production while minimizing adverse environmental impacts, including the runoff or leaching of excess nutrients (Rice et al., 2006; Slaton et al., 2009). Various testing methods have been introduced, including acids, salts and chelates to estimate nutrient availability in soils (Cancela et al., 2002). However, no universal standards have been achieved (Wang et al., 2004). Disagreements on nutrient availability and fertilizer recommendations for similar soils and crops as a result of different extraction methods are well documented (Cancela et al., 2002; Wang et al., 2004). Extractants vary in their extracting capabilities and therefore dissimilar extraction methods account for different degrees of nutrient availability.

The Everglades Agricultural Area (EAA) in south Florida was historically a seasonally-flooded prairie ecosystem, but was converted to agricultural use by drainage in the early 1900s. The soils are primarily Histosols with high organic matter content, and contain high nitrogen $(\mathrm{N})$ and low $\mathrm{P}$ and micronutrient concentrations that require supplemental fertilization (Snyder, 2005; Ye et al., 2009). Upon drainage and land use conversion, high decomposition rates of these drained Histosols resulted in subsidence and a decreased depth to the underlying bedrock. The current estimate of soil loss is $1.5 \mathrm{~cm} \mathrm{yr}^{-1}$, and many soils are less than $51 \mathrm{~cm}$ in depth, such as those classified as Dania series (Shih et al., 1998; Snyder, 2005). Long-term cultivation of these drained soils, specifically the use of tillage, coupled with soil oxidation has resulted in incorporation of bedrock calcium carbonate $\left(\mathrm{CaCO}_{3}\right)$ into surface soil and has gradually increased the $\mathrm{pH}$ from the historic 5.0-5.5 to approximately 7.0-7.5 today (Snyder, 2005). As a result, $\mathrm{P}$ and micronutrient availability to crops has decreased and necessitated new fertilizer management practices to maintain nutrients at concentrations sufficient for optimal crop growth. Application of elemental sulfur (S) is recommended in the EAA when soil $\mathrm{pH}$ exceeds 6.6 for the purpose of reducing $\mathrm{pH}$ and therefore increasing $\mathrm{P}$ and micronutrient availability (Schueneman, 2001). The recommendation rate of $448 \mathrm{~kg} \mathrm{~S} \mathrm{ha}^{-1}$ was initially established in 1985 (Anderson, 1985), but due to the changes in soil conditions since 1985, revision of this recommendation may be required. The increasing buffering capacity of these calcareous Histosols is likely to counteract the acidifying effects of elemental S oxidation, with the continued loss of soil depth occurring since these S recommendations were developed. Thus, effects of amendments may only be temporary and minimally effective (Beverly and Anderson, 1986). There is a need to determine the level of S application 
producing favorable responses in terms of nutrient availability and sugarcane yield. These results can then be used to help formulate fertilizer and nutrient management solutions for better sugarcane production in the EAA. The objective of this research was to evaluate various $S$ application rates for their effects on nutrient availability during the growing season and to assess the effectiveness of three soil test extractants in predicting sugarcane yield.

\section{MATERIALS AND METHODS}

\section{Site Description}

The experimental field is located in the central EAA on Dania muck (euic, hyperthermic, shallow Lithic Haplosaprist) with a depth to bedrock of approximately $50 \mathrm{~cm}$. The experimental design was a randomized complete block with four S application rates and four field replications, with four sampling times encompassing the entire growing season. Each field plot measured $9 \mathrm{~m} \times 13 \mathrm{~m}$ and consisted of 6 rows of sugarcane (Saccharum spp.) cultivar 'CP 89-2143' that was planted in November 2007 and harvested in February 2009. Elemental granular S (90\%) was applied at rates of 0, 112, 224 , and $448 \mathrm{~kg} \mathrm{~S} \mathrm{ha}^{-1}$ to the furrow and covered after planting. Other fertilization was provided using the typical recommendations and guidelines for this region and soil type (Gilbert and Rice, 2006). Fertilizers were soil-applied prior to planting and all field plots received $17 \mathrm{~kg} \mathrm{~N} \mathrm{ha}^{-1}$ and $37 \mathrm{~kg} \mathrm{P} \mathrm{ha}^{-1}$ as monoammonium phosphate, $228 \mathrm{~kg}$ potassium (K) ha $\mathrm{ha}^{-1}$ as potassium chloride $(\mathrm{KCl}), 8.5 \mathrm{~kg}$ manganese $(\mathrm{Mn}) \mathrm{ha}^{-1}, 4.5 \mathrm{~kg}$ copper $(\mathrm{Cu}) \mathrm{ha}^{-1}, 5.6 \mathrm{~kg}$ iron $(\mathrm{Fe}) \mathrm{ha}^{-1}, 2.8 \mathrm{~kg} \mathrm{Zn} \mathrm{ha} \mathrm{ha}^{-1}$, and $1.1 \mathrm{~kg}$ boron (B) $\mathrm{ha}^{-1}$. All plots received common cultural practices including tillage and herbicide application. Water was applied as needed via seepage irrigation in field ditches approximately $182 \mathrm{~m}$ apart.

\section{Soil Sampling and Analysis}

Soil samples were collected before planting and fertilizer application and then in January, May, August, and December 2008, corresponding to approximately $0,2,6,9$, and 13 months after planting, respectively. Twelve soil $(0-15 \mathrm{~cm})$ cores $(2.54 \mathrm{~cm}$ diameter $)$ were randomly collected within each of the 16 field plots and composited. Samples were homogenized after the removal of visible plant residues and stored at $4^{\circ} \mathrm{C}$.

Soil $\mathrm{pH}$ was measured using a soil to water ratio of $1: 3$ after equilibration for $30 \mathrm{~min}$. Organic matter content was determined by loss-on-ignition at $550^{\circ} \mathrm{C}$ for $4 \mathrm{hr}$ (Wright et al., 2008). Dissolved organic C (DOC) was measured by extraction with $0.5 \mathrm{M}$ potassium sulfate $\left(\mathrm{K}_{2} \mathrm{SO}_{4}\right)$ and analyzed with a TOC-5050A total organic $\mathrm{C}$ analyzer (Shimadzu, Norcross, GA, USA). Extractable ammonium $\left(\mathrm{NH}_{4}\right)-\mathrm{N}$ and nitrate $\left(\mathrm{NO}_{3}\right)-\mathrm{N}$ were determined by extraction with $2 M \mathrm{KCl}$ followed by colorimetric analysis (Castillo and 
Wright, 2008). Water extractable sulfate $\left(\mathrm{SO}_{4}\right)-\mathrm{S}$ was analyzed by ionic chromatography after shaking $3 \mathrm{~g}$ soil with $25 \mathrm{~mL}$ water for $0.5 \mathrm{hr}$, followed by filtering through Whatman No. 41 filter paper (Gharmakher et al., 2009).

Three different extractants were tested in this study: water, $0.5 \mathrm{~N}$ acetic acid, and Mehlich-3. Water and acetic acid are the soil test extractants for use on muck soils in Florida, and Mehlich-3 is the soil test extractant for sandy soils (Morgan et al., 2009; Mylavarapu, 2009). Phosphorus concentrations for different extracts were determined using the ascorbic acid-molybdenum blue method (Kuo, 1996) after shaking $4 \mathrm{~mL}$ air-dry soil with $50 \mathrm{~mL}$ of extractant for $50 \mathrm{~min}$, followed by filtering through Whatman No. 2 (acetic acid extraction) and No. 5 (water and Mehlich-3 extraction) filter paper, respectively. Macro- and micronutrient concentrations for different extractants were then analyzed by inductively coupled plasma atomic emission spectrometry (ICP).

\section{Sugar Yield}

Harvestable stalks were counted in 2 of the 4 middle rows of each plot in August. Stalk weights were determined by cutting and weighing 20 stalks from 2 of the middle 4 rows of each plot ( 40 stalks total) in February 2009. Sugarcane yield ( $\mathrm{Mg}$ cane $\mathrm{ha}^{-1}$ ) was calculated by multiplying stalk number by stalk weight, and dividing by unit area. Ten stalks from each plot were milled and the crushed juice analyzed for Brix and Pol, and sugar concentration of harvested cane ( $\mathrm{kg}$ sugar $\mathrm{Mg}_{\text {cane }}{ }^{-1}$ ) was determined according to the theoretical recoverable sugar method (Glaz et al., 2002). Sugar yield $\left(\mathrm{Mg} \mathrm{ha}{ }^{-1}\right)$ was calculated as the product of sugarcane yield and sugar concentration.

\section{Statistical Analysis}

A mixed model was fit using restricted maximum likelihood in the MIXED procedure of SAS (SAS Institute, Cary, NC, USA). The fixed effects were $S$ application rate, time and their interaction, with block as a random effect. Degrees of freedom were adjusted using the Kenward-Roger adjustment. An exponential covariance structure was used to model the correlation among observations taken from the same plot over time. Significant differences among individual treatments and time intervals were determined with Tukey's test at $\alpha=0.05$. Pearson correlation analysis was performed to assess relationships between variables. Stepwise multiple regression was conducted to evaluate the relative importance of extractable nutrients in predicting sugar yield. A $p$ value of 0.1 and 0.05 was used as the entry and staying values, respectively, in the stepwise selection method (Majchrzak et al., 2001). All statistical analyses were carried out with SAS 9.1 (SAS Institute). 


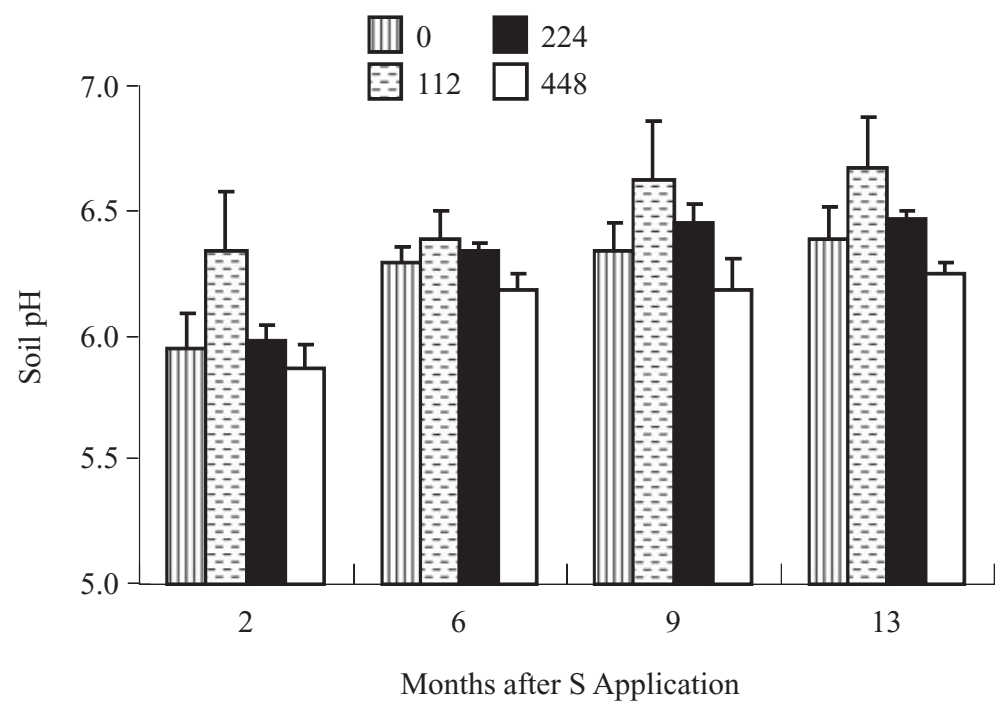

FIGURE 1 Soil $\mathrm{pH}$ changes in response to different $\mathrm{S}$ application rates $\left(0,112,224\right.$, and $\left.448 \mathrm{~kg} \mathrm{~S} \mathrm{ha}^{-1}\right)$ throughout the sugarcane growing season. Error bars represent the standard error of the mean.

\section{RESULTS AND DISCUSSION}

\section{Soil pH}

Soil $\mathrm{pH}$ was generally not affected by $\mathrm{S}$ application (Figure 1). The background $\mathrm{pH}$ prior to $\mathrm{S}$ application was 6.2 , which did not differ from soils collected during the growing season. The limited effect of acidification may result from a $\mathrm{S}$ application rate too low to cause a change in $\mathrm{pH}$ and from the high buffering capacity of this calcareous organic soil. Soils with high concentrations of carbonates and bicarbonates are highly buffered against acidification (Rogovska et al., 2007). The buffering effects often take place more slowly than the formation of sulfuric acid from elemental S (Deubel et al., 2007). When the original S recommendation for sugarcane of $448 \mathrm{~kg}$ $\mathrm{S} \mathrm{ha}^{-1}$ was established years ago, soil $\mathrm{pH}$ in the EAA was considerably lower. However, the rise in $\mathrm{pH}$ and decrease in soil depth to bedrock since that time increased the capacity of these soils to resist changes in $\mathrm{pH}$. Thus, higher $\mathrm{S}$ application rates may be necessary to produce the same response as $448 \mathrm{~kg}$ $\mathrm{ha}^{-1}$ did in the 1980s (Anderson, 1985). A limited reduction in soil $\mathrm{pH}$ after $\mathrm{S}$ application was also observed in other studies of calcareous soils (Hassan and Olson, 1966).

\section{Dissolved Organic $\mathrm{C}$ and Extractable $\mathrm{N}$}

Application of $\mathrm{S}$ at a range from 0 to $448 \mathrm{~kg} \mathrm{~S} \mathrm{ha}^{-1}$ did not affect DOC, but the concentrations varied seasonally (Figure 2). Averaged across treatments, DOC significantly increased from $2\left(1346 \mathrm{mg} \mathrm{kg}^{-1}\right)$ to 6 months 

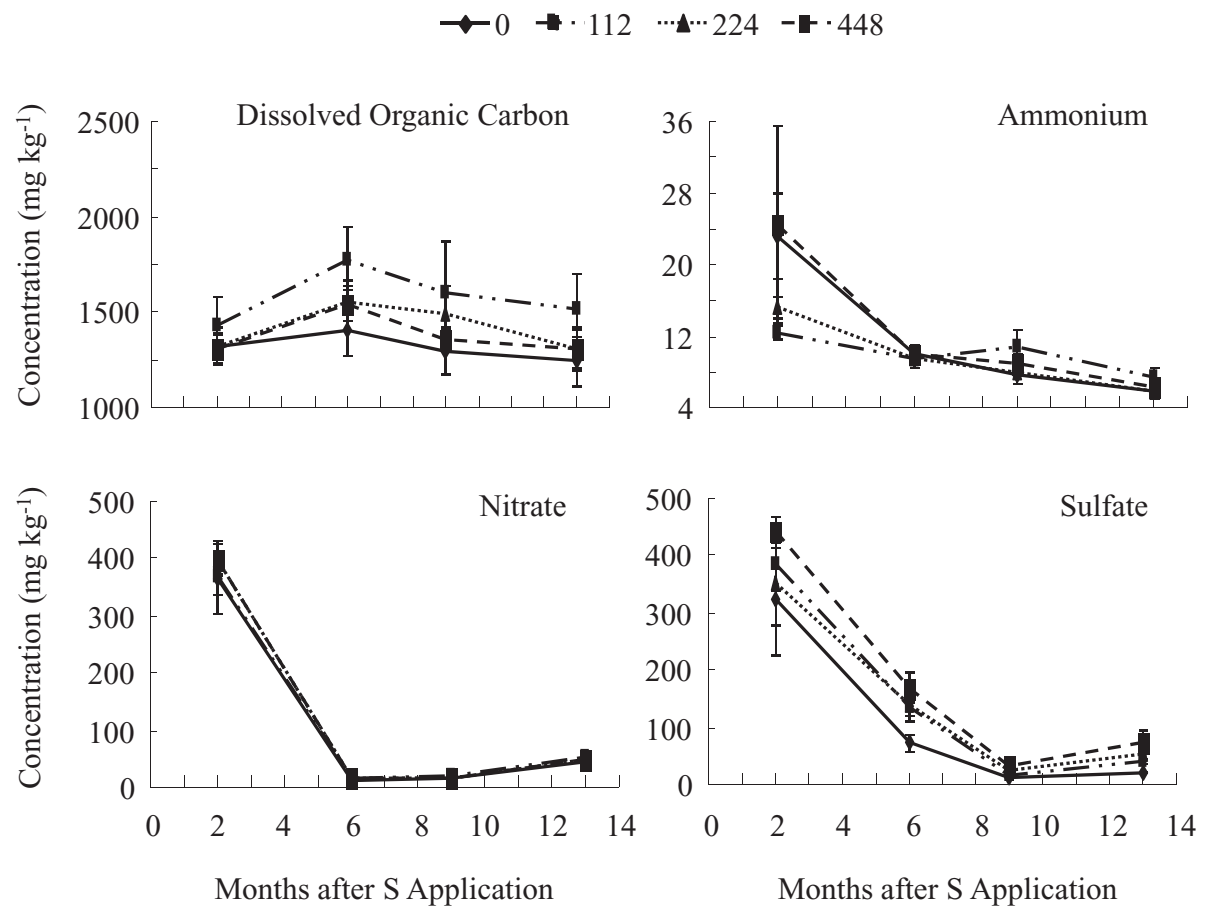

FIGURE 2 Seasonal dynamics of dissolved organic $\mathrm{C}$, extractable $\mathrm{NH}_{4}-\mathrm{N}, \mathrm{NO}_{3}-\mathrm{N}$, and $\mathrm{SO}_{4}-\mathrm{S}$ after $\mathrm{S}$ application at $0,112,224$, and $448 \mathrm{~kg} \mathrm{~S} \mathrm{ha}^{-1}$. Error bars represent the standard error of the mean.

(1572 $\mathrm{mg} \mathrm{kg}^{-1}$ ), but then decreased toward the end of the growing season. Extractable $\mathrm{NH}_{4}-\mathrm{N}$ and $\mathrm{NO}_{3}-\mathrm{N}$ were not influenced by $\mathrm{S}$ application, but concentrations fluctuated during the growing season (Figure 2). Extractable $\mathrm{NH}_{4}-\mathrm{N}$ significantly decreased from $2\left(19 \mathrm{mg} \mathrm{kg}^{-1}\right)$ to 6 months $\left(10 \mathrm{mg} \mathrm{kg}^{-1}\right.$ ), while extractable $\mathrm{NO}_{3}-\mathrm{N}$ exhibited the same trend from 2 (383 $\mathrm{mg} \mathrm{kg}^{-1}$ ) to 6 months $\left(16 \mathrm{mg} \mathrm{kg}^{-1}\right)$. Oxidation of the muck soil provides most of the $\mathrm{N}$ requirement for sugarcane grown in the EAA (Gilbert and Rice, 2006). However, the soil $\mathrm{N}$ pool can change rapidly under the impacts of environmental (precipitation, temperature) and management (tillage, irrigation) factors (Rice et al., 2006). Considering the fact that sugarcane biomass accumulation is the greatest during the rainy season of the summer months (Rice et al., 2006), it was likely that plant uptake and leaching losses contributed to the low $\mathrm{NO}_{3}-\mathrm{N}$ concentrations as the growing season progressed.

\section{Phosphorus}

Sulfur application at $448 \mathrm{~kg} \mathrm{~S}^{-1}$ significantly increased concentrations of acetic acid, Mehlich-3, and water-extractable $\mathrm{P}$ at 2 months (Figure 3), suggesting increased $\mathrm{P}$ availability to sugarcane in the short-term caused by 


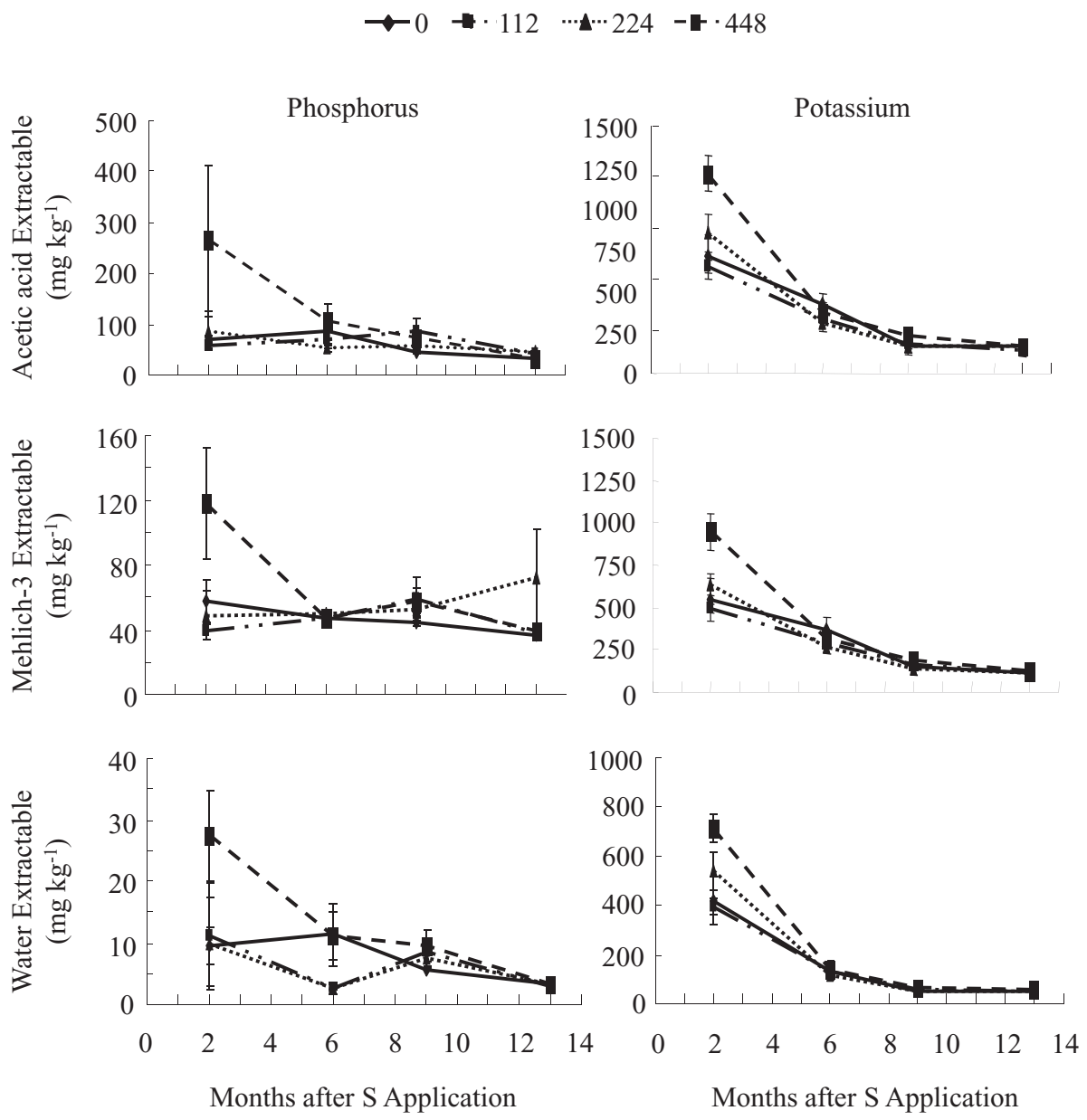

FIGURE 3 Seasonal dynamics of acetic acid, Mehlich-3, and water extractable $\mathrm{P}$ and K after $\mathrm{S}$ amendment at $0,112,224$, and $448 \mathrm{~kg} \mathrm{~S}^{-1}$. Error bars represent the standard error of the mean.

S application (Codling, 2008). There are two primary mechanisms by which $\mathrm{S}$ application could influence $\mathrm{P}$ availability, including the lowering of soil pH and replacement of phosphate $\left(\mathrm{PO}_{4}\right)$ with $\mathrm{SO}_{4}$ (Gabriel et al., 2008), and the release of $\mathrm{P}$ from association with $\mathrm{Fe}$, aluminum $(\mathrm{Al})$, and $\mathrm{Ca}$ caused by $\mathrm{pH}$ reduction (Jaggi et al., 2005; Ye et al., 2010). However, increased P availability was not observed at later months indicating limited long-term effects of $\mathrm{S}$ on the reduction in soil $\mathrm{pH}$ due to the high buffering capacity of this calcareous organic soil (Snyder, 2005).

Acetic acid extractable $\mathrm{P}$ decreased progressively during the season (Figure 3). The concentrations at 13 months were $214 \%$ lower than at 2 months, $107 \%$ lower than at 6 months, and $75 \%$ lower than at 9 months. Similarly, water-extractable $\mathrm{P}$ decreased from 2 months $\left(15 \mathrm{mg} \mathrm{kg}^{-1}\right)$ to 13 months (3 $\mathrm{mg} \mathrm{kg}^{-1}$ ), but Mehlich-3 extractable $\mathrm{P}$ did not change during the same 
TABLE 1 Comparisons of soil test extractants on concentrations of available nutrients $\left(\mathrm{mg} \mathrm{kg}^{-1}\right)$. Values denote the mean across $\mathrm{S}$ rates and time with standard error values in parenthesis

\begin{tabular}{lccc}
\hline & Acetic acid & Mehlich-3 & Water \\
\hline $\mathrm{P}$ & $76(11)$ & $53(4)$ & $8(1)$ \\
$\mathrm{K}$ & $387(41)$ & $313(32)$ & $188(27)$ \\
$\mathrm{Ca}$ & $18936(600)$ & $16621(287)$ & $532(54)$ \\
$\mathrm{Mg}$ & $957(59)$ & $664(12)$ & $76(8)$ \\
$\mathrm{Cu}$ & $0.19(0.02)$ & $0.51(0.08)$ & $0.20(0.01)$ \\
$\mathrm{Mn}$ & $15(0.8)$ & $4.7(0.1)$ & $0.2(0)$ \\
$\mathrm{Fe}$ & $10(0.4)$ & $7(0.2)$ & $11(0.6)$ \\
$\mathrm{Zn}$ & $3.2(0.3)$ & $2.9(0.2)$ & $0.3(0)$ \\
\hline
\end{tabular}

period. The EAA soils are historically $\mathrm{P}$ limited and sugarcane production requires supplemental $P$ fertilization (Morgan et al., 2009). Therefore, the reduction in acetic acid and water extractable $\mathrm{P}$ during the season was likely a result of sugarcane uptake. Seasonal trends in $\mathrm{P}$ concentrations were expected to show declines from planting to harvest, corresponding to uptake of extractable $\mathrm{P}$ by sugarcane. However, $\mathrm{P}$ mineralized from soil organic matter also contributes to the available $\mathrm{P}$ pool.

Across treatments and sampling times, acetic acid extracted $834 \%$ more $\mathrm{P}$ than water, while Mehlich-3 extracted $559 \%$ more $\mathrm{P}$ than water (Table 1). No significant difference was found between the amounts of $\mathrm{P}$ extracted by acetic acid and Mehlich-3. Water primarily extracts $\mathrm{P}$ in soil solution, while Mehlich-3 and acetic acid also extract $\mathrm{P}$ adsorbed or complexed with $\mathrm{Ca}$, $\mathrm{Mg}, \mathrm{Fe}$, and $\mathrm{Al}$, in addition to soluble P (Wright et al., 2007; Wright, 2009). Thus, it was not surprising that Mehlich-3 and acetic acid extracts contained more $\mathrm{P}$ than water.

\section{Potassium}

Sulfur application at the highest rates significantly increased K availability at two months (Figure 3), but the treatment effect was not observed at subsequent sampling times. At two months, acetic acid extractable $\mathrm{K}$ for soils receiving $448 \mathrm{~kg} \mathrm{~S}^{-1}$ (1214 $\mathrm{mg} \mathrm{kg}^{-1}$ ) was significantly higher than for soils receiving $112 \mathrm{~kg} \mathrm{~S} \mathrm{ha}^{-1}\left(647 \mathrm{mg} \mathrm{kg}^{-1}\right)$ and unamended soil $\left(708 \mathrm{mg} \mathrm{kg}^{-1}\right)$. Likewise, Mehlich-3 extractable K for soils amended with the highest rates (949 $\mathrm{mg} \mathrm{K} \mathrm{kg}^{-1}$ ) was significantly higher than soils receiving $112 \mathrm{~kg} \mathrm{~S} \mathrm{ha}^{-1}$ (493 $\mathrm{mg} \mathrm{K} \mathrm{kg}^{-1}$ ) and unamended soil (549 $\mathrm{mg} \mathrm{kg}^{-1}$ ). Water extractable $\mathrm{K}$ was only different between soils receiving $112\left(395 \mathrm{mg} \mathrm{kg}{ }^{-1}\right)$ and 448 $\mathrm{kg} \mathrm{S} \mathrm{ha}{ }^{-1}\left(713 \mathrm{mg} \mathrm{kg}{ }^{-1}\right)$. Acetic acid extractable $\mathrm{K}$ decreased $440 \%$ from 2 months to 13 months, while during the same period Mehlich-3 and water extractable K decreased $448 \%$ and $891 \%$, respectively (Figure 3). Despite the fact that EAA soils have high cation-exchange capacities, $\mathrm{K}$ is usually weakly held on the exchange sites (Gilbert and Rice, 2006). Therefore, K movement 
out of the soil profile occurs readily depending on precipitation patterns. The short-term stimulatory effect of $\mathrm{S}$ on extractable $\mathrm{K}$ concentrations was likely attributed to the replacement of $\mathrm{K}^{+}$by $\mathrm{H}^{+}$at adsorbing sites, while plant uptake and leaching were responsible for seasonal decreases in $\mathrm{K}$ availability.

Averaged across treatments and sampling times, acetic acid extracted the same amounts of $\mathrm{K}$ as Mehlich-3 (Table 1). However, acetic acid and Mehlich-3 extracted $106 \%$ and $66 \%$ more of $\mathrm{K}$ than water. Correlation analysis revealed that water extractable $\mathrm{K}$ was highly correlated to acetic acid $\left(\mathrm{R}^{2}=0.98\right)$ and Mehlich-3 extractable $\mathrm{K}\left(\mathrm{R}^{2}=0.96\right)$, while the later two were also strongly correlated $\left(\mathrm{R}^{2}=0.99\right)$, indicating that the three extractants may indeed extract the same pools of $\mathrm{K}$, but that acetic acid and Mehlich-3 extract more tightly bound K.

\section{Calcium}

None of the extractable Ca concentrations exhibited S effects, but all displayed seasonal fluctuation (Figure 4). Both acetic acid and water extractable Ca decreased significantly from 2 to 9 months, and then increased to 13 months. Mehlich-3 extractable Ca was highest at 9 months (19516 mg kg $\mathrm{mg}^{-1}$ ), followed by 13 (17359 $\left.\mathrm{mg} \mathrm{kg}^{-1}\right), 2$ (14386 $\mathrm{mg} \mathrm{kg}^{-1}$ ), and 6 months $\left(15224 \mathrm{mg} \mathrm{kg}^{-1}\right.$ ). Acetic acid extractable Ca was $3457 \%$ higher than water-extractable Ca, while Mehlich-3 extracts had 3022\% more Ca than water extracts.

\section{Magnesium}

Sulfur application did not affect $\mathrm{Mg}$ availability (Figure 4). Acetic acid extractable $\mathrm{Mg}$ decreased significantly from $2\left(1735 \mathrm{mg} \mathrm{kg}^{-1}\right)$ to $6(665 \mathrm{mg}$ $\mathrm{kg}^{-1}$ ) months, but remained constant to 9 months $\left(671 \mathrm{mg} \mathrm{kg}^{-1}\right)$. Mehlich3 extractable $\mathrm{Mg}$ increased from $6\left(580 \mathrm{mg} \mathrm{kg}^{-1}\right)$ to 9 months (774 $\mathrm{mg}$ $\mathrm{kg}^{-1}$ ) and then decreased to 13 months $\left(711 \mathrm{mg} \mathrm{kg}^{-1}\right)$. Water extractable $\mathrm{Mg}$ decreased gradually during the season, being 307\% lower at 13 than 2 months. Acetic acid extracted $44 \%$ more Mg than Mehlich-3, while extracting $1155 \%$ more $\mathrm{Mg}$ than water (Table 1 ).

\section{Sulfur}

Sulfur application significantly increased $\mathrm{SO}_{4}$ concentrations as a result of $\mathrm{S}$ oxidation (Jaggi et al., 2005) (Figure 2). Extractable $\mathrm{SO}_{4}-\mathrm{S}$ in soils receiving $448 \mathrm{~kg} \mathrm{~S} \mathrm{ha}^{-1}$ was $131 \%, 201 \%$, and $270 \%$ higher than unamended soils at 6, 9, and 13 months, respectively. Similar to extractable $\mathrm{K}, \mathrm{SO}_{4}$ concentrations decreased significantly from $2\left(376 \mathrm{mg} \mathrm{kg}^{-1}\right)$ to 6 months $\left(129 \mathrm{mg} \mathrm{kg}^{-1}\right)$ and continued to decrease from 6 to 9 months $\left(21 \mathrm{mg} \mathrm{kg}^{-1}\right)$. 


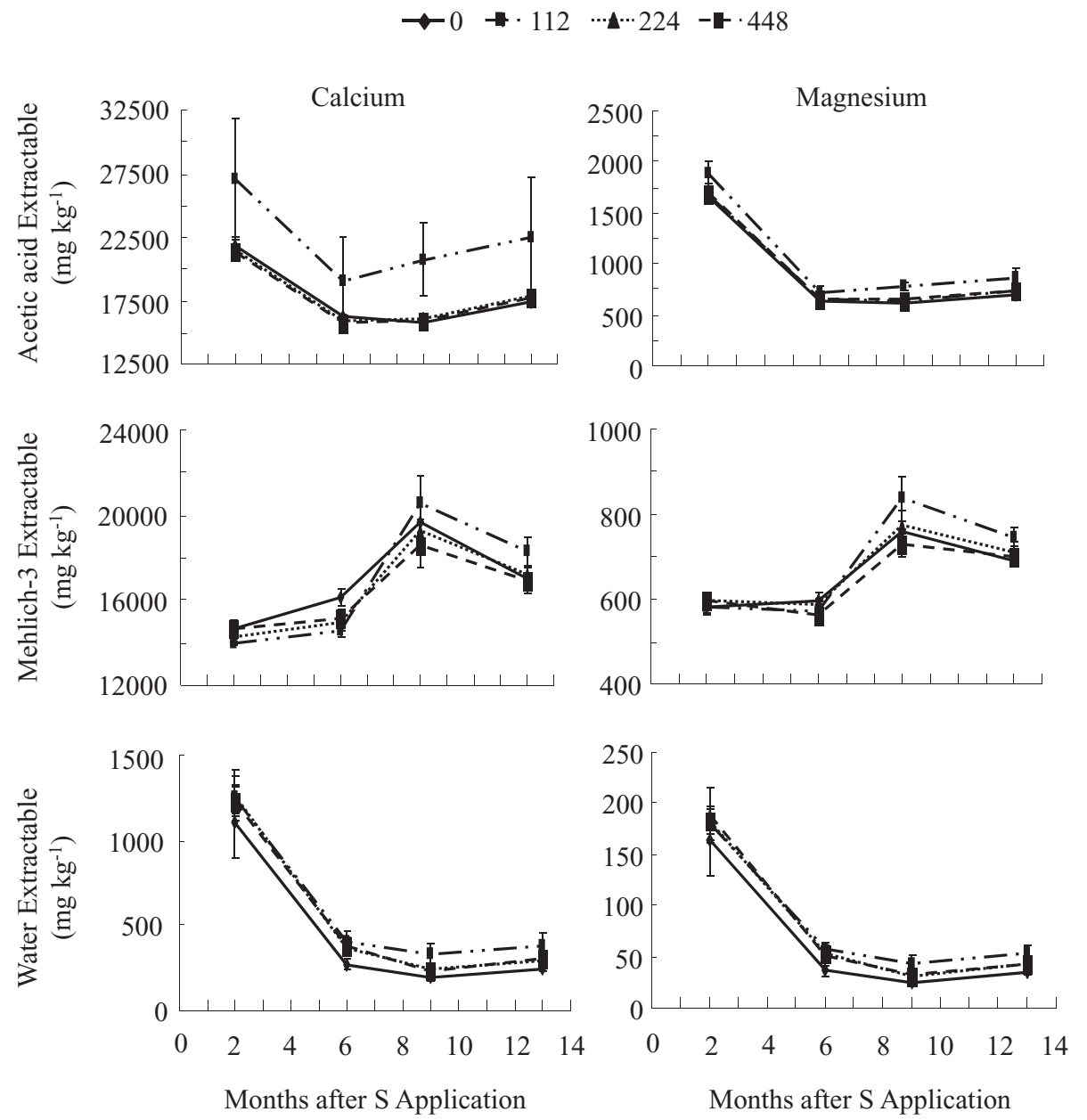

FIGURE 4 Seasonal dynamics of acetic acid, Mehlich-3, and water extractable Ca and $\mathrm{Mg}$ after $\mathrm{S}$ amendment at $0,112,224$, and $448 \mathrm{~kg} \mathrm{~S} \mathrm{ha}^{-1}$. Error bars represent the standard error of the mean.

In the EAA, soil oxidation generally supplies sufficient $\mathrm{S}$ to satisfy sugarcane nutrient requirements (Gilbert and Rice, 2006). Therefore, there is potential for $\mathrm{S}$ application at high rates to increase $\mathrm{SO}_{4}$ concentrations in soil to the point of increasing the risk of $\mathrm{SO}_{4}$ export from fields. Lower $\mathrm{SO}_{4}-\mathrm{S}$ concentrations at 6 and 9 months were likely due to $\mathrm{SO}_{4}$ uptake by sugarcane and losses as runoff or leaching during precipitation events.

\section{Copper}

Extractable copper was not affected by $\mathrm{S}$ application at any time during the growing season (Figure 5). Acetic acid extractable $\mathrm{Cu}$ decreased significantly from $2\left(0.3 \mathrm{mg} \mathrm{kg}^{-1}\right)$ to 9 months $\left(0.1 \mathrm{mg} \mathrm{kg}^{-1}\right)$, while 

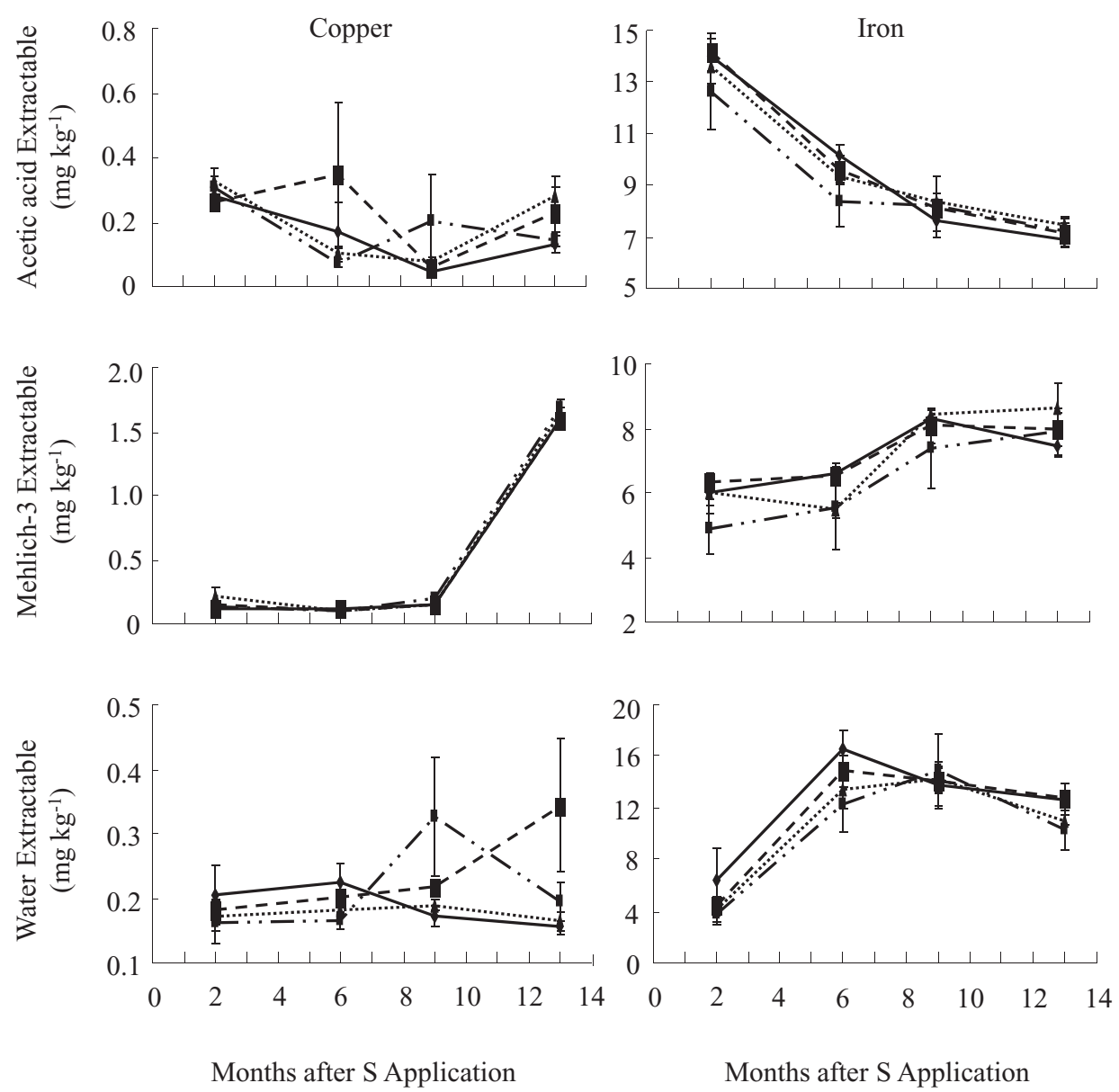

FIGURE 5 Seasonal dynamics of acetic acid, Mehlich-3, and water extractable Cu and Fe after S amendment at $0,112,224$, and $448 \mathrm{~kg} \mathrm{~S}^{-1}$. Error bars represent the standard error of the mean.

water-extractable $\mathrm{Cu}$ remained unchanged during the season. Mehlich-3 extractable $\mathrm{Cu}$ increased from $6\left(0.1 \mathrm{mg} \mathrm{kg}^{-1}\right)$ to 9 months $\left(0.2 \mathrm{mg} \mathrm{kg}^{-1}\right)$ and then to 13 months $\left(1.6 \mathrm{mg} \mathrm{kg}^{-1}\right)$. Across treatments and sampling times, acetic acid and water extracted similar amounts of $\mathrm{Cu}$, but both extracted less than Mehlich-3 (Table 1).

\section{Iron}

Similar to $\mathrm{Cu}$, extractable Fe did not respond to any rate of $\mathrm{S}$ application, but did fluctuate seasonally (Figure 5). Acetic acid extractable Fe decreased significantly from $2\left(13.6 \mathrm{mg} \mathrm{kg}^{-1}\right)$ to 6 months $\left(9.4 \mathrm{mg} \mathrm{kg}^{-1}\right)$ and toward the end of the season $\left(7.2 \mathrm{mg} \mathrm{kg}^{-1}\right)$. Inversely, Mehlich-3 extractable $\mathrm{Fe}$ 
increased from $2\left(5.8 \mathrm{mg} \mathrm{kg}^{-1}\right)$ to 13 months $\left(8.0 \mathrm{mg} \mathrm{kg}^{-1}\right)$. Water extracts contained similar amounts of $\mathrm{Fe}$ as acetic acid, but extracted $61 \%$ more $\mathrm{Fe}$ than Mehlich-3 (Table 1).

\section{Manganese}

The availability of $\mathrm{Mn}$ was not affect by $\mathrm{S}$ application, but varied during the season (Figure 6). Similar to $\mathrm{K}$ and Fe, acetic acid extractable $\mathrm{Mn}$ decreased incrementally from $2\left(23.9 \mathrm{mg} \mathrm{kg}^{-1}\right)$ to 13 months $\left(9.4 \mathrm{mg} \mathrm{kg}^{-1}\right)$. Mehlich-3 extractable Mn decreased from $2\left(4.2 \mathrm{mg} \mathrm{kg}{ }^{-1}\right)$ to 6 months (3.7 $\left.\mathrm{mg} \mathrm{kg}^{-1}\right)$, and then increased from 6 to 9 months $\left(5.3 \mathrm{mg} \mathrm{kg}^{-1}\right)$. Acetic acid extractable Mn was $7900 \%$ higher than water-extractable $\mathrm{Mn}$, while Mehlich-3 extracts had $2414 \%$ more Mn than water extracts.

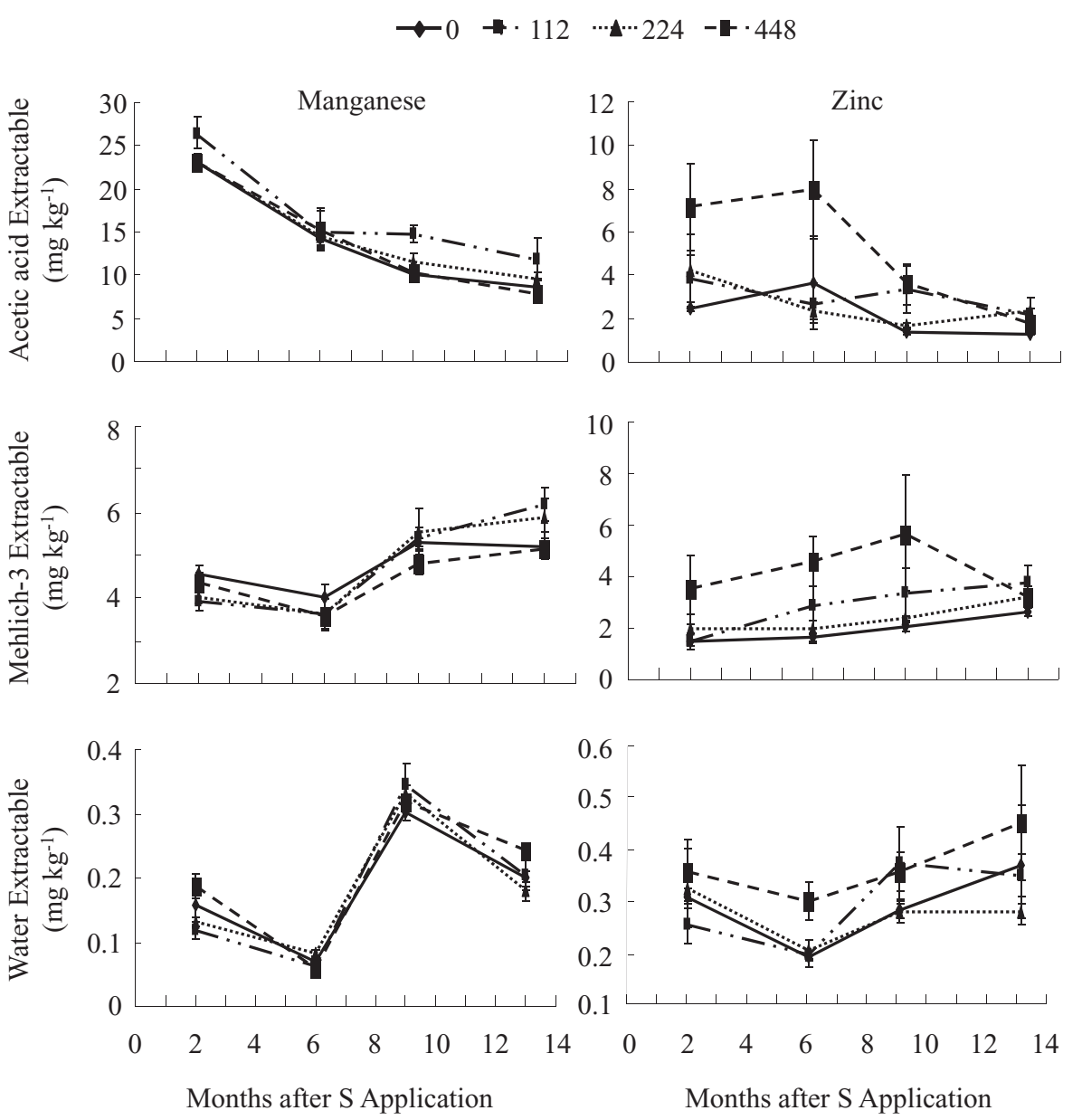

FIGURE 6 Seasonal dynamics of acetic acid, Mehlich-3, and water extractable Mn and Zn after S amendment at $0,112,224$, and $448 \mathrm{~kg} \mathrm{~S} \mathrm{ha}^{-1}$. Error bars represent the standard error of the mean. 


\section{Zinc}

Acetic acid-extractable $\mathrm{Zn}$ in soils receiving $448 \mathrm{~kg} \mathrm{~S} \mathrm{ha}^{-1}\left(7.2 \mathrm{mg} \mathrm{kg}^{-1}\right)$ was significantly higher than for unamended soils $\left(2.5 \mathrm{mg} \mathrm{kg}^{-1}\right)$ at 2 months (Figure 6). However, the stimulating effects were not observed beyond 2 months. Mehlich-3 extractable $\mathrm{Zn}$ did not exhibit any treatment effects during the growing season. Interestingly, at 6 months after $\mathrm{S}$ application, water-extractable $\mathrm{Zn}$ for soils receiving $448 \mathrm{~kg} \mathrm{~S} \mathrm{ha}{ }^{-1}\left(0.3 \mathrm{mg} \mathrm{kg}^{-1}\right)$ was significantly higher than for soils receiving $112 \mathrm{~kg} \mathrm{~S} \mathrm{ha}{ }^{-1}\left(0.2 \mathrm{mg} \mathrm{kg}^{-1}\right)$ and unamended soils $\left(0.2 \mathrm{mg} \mathrm{kg}^{-1}\right)$. Similar to $\mathrm{K}, \mathrm{Fe}$, and $\mathrm{Mn}$, acetic acid extractable $\mathrm{Zn}$ decreased gradually from 2 to 13 months. The decreases in nutrient availability can be attributed to losses of nutrient as leaching and sugarcane uptake. Meanwhile, fixation and chelating of $\mathrm{Zn}$ and other micronutrient cations to organic matter, clay minerals, and carbonates may also remove it from the available pools. Zinc concentrations in acetic acid and Mehlich-3 extracts did not differ, but both extracted $943 \%$ and $817 \%$ more $\mathrm{Zn}$ than water extracts, respectively (Table 1).

\section{Soil Properties and Micronutrient Availability}

Organic matter and soil pH are two major properties that influence nutrient availability and mobility (Herencia et al., 2008; Provin et al., 2008). Organic matter provides ligands that chelate the micronutrients and promotes the formation of soluble micronutrient-organic matter complexes and therefore increases nutrient availability (Herencia et al., 2008). However, organic matter can also immobilize nutrients through the same complexation mechanism (Wei et al., 2006). In the present study, organic matter content was only significantly correlated with Mehlich-3 extractable Fe and acetic acid extractable Mn (Tables 2, 3, and 4), indicating that soil organic matter

TABLE 2 Pearson correlation coefficients ( $\mathrm{r}$ ) between $\mathrm{pH}$, organic matter content, and concentrations of acetic acid-extractable nutrients $(n=64)$

\begin{tabular}{lcccccccccc}
\hline & $\mathrm{pH}$ & $\mathrm{OM}$ & $\mathrm{P}$ & $\mathrm{K}$ & $\mathrm{Ca}$ & $\mathrm{Mg}$ & $\mathrm{Cu}$ & $\mathrm{Fe}$ & $\mathrm{Mn}$ & $\mathrm{Zn}$ \\
\hline $\mathrm{pH}$ & 1 & & & & & & & & & \\
$\mathrm{OM}$ & $-0.45^{*}$ & 1 & & & & & & & & \\
$\mathrm{P}$ & -0.31 & $\mathrm{NS}$ & 1 & & & & & & & \\
$\mathrm{~K}$ & -0.61 & $\mathrm{NS}$ & 0.60 & 1 & & & & & & \\
$\mathrm{Ca}$ & 0.29 & -0.71 & $\mathrm{NS}$ & 0.32 & 1 & & & & & \\
$\mathrm{Mg}$ & -0.31 & $\mathrm{NS}$ & $\mathrm{NS}$ & 0.79 & 0.66 & 1 & & & & \\
$\mathrm{Cu}$ & $\mathrm{NS}$ & $\mathrm{NS}$ & $\mathrm{NS}$ & 0.25 & $\mathrm{NS}$ & 0.38 & 1 & & & \\
$\mathrm{Fe}$ & -0.51 & $\mathrm{NS}$ & 0.37 & 0.80 & $\mathrm{NS}$ & 0.78 & 0.41 & 1 & & \\
$\mathrm{Mn}$ & $\mathrm{NS}$ & -0.28 & 0.26 & 0.73 & 0.64 & 0.88 & 0.47 & 0.78 & 1 & \\
$\mathrm{Zn}$ & -0.29 & $\mathrm{NS}$ & 0.66 & 0.49 & NS & NS & 0.55 & 0.41 & 0.38 & 1 \\
\hline
\end{tabular}

OM, organic matter content; *, significant at $\alpha=0.05$; NS, not significant. 
TABLE 3 Pearson correlation coefficients (r) between soil $\mathrm{pH}$, organic matter content, and concentrations of Mehlich-3-extractable nutrients $(\mathrm{n}=64)$

\begin{tabular}{|c|c|c|c|c|c|c|c|c|c|c|}
\hline & $\mathrm{pH}$ & $\mathrm{OM}$ & $\mathrm{P}$ & $\mathrm{K}$ & $\mathrm{Ca}$ & $\mathrm{Mg}$ & $\mathrm{Cu}$ & $\mathrm{Fe}$ & $\mathrm{Mn}$ & $\mathrm{Zn}$ \\
\hline $\mathrm{pH}$ & 1 & & & & & & & & & \\
\hline $\mathrm{OM}$ & $-0.45^{*}$ & 1 & & & & & & & & \\
\hline $\mathrm{P}$ & -0.34 & NS & 1 & & & & & & & \\
\hline K & -0.61 & NS & 0.52 & 1 & & & & & & \\
\hline $\mathrm{Ca}$ & 0.35 & -0.29 & NS & -0.58 & 1 & & & & & \\
\hline $\mathrm{Mg}$ & 0.38 & NS & NS & -0.54 & 0.91 & 1 & & & & \\
\hline $\mathrm{Cu}$ & 0.28 & NS & NS & -0.44 & NS & 0.32 & 1 & & & \\
\hline $\mathrm{Fe}$ & NS & 0.37 & NS & -0.44 & 0.60 & 0.66 & 0.38 & 1 & & \\
\hline Mn & 0.36 & NS & NS & -0.45 & 0.67 & 0.77 & 0.57 & 0.71 & 1 & \\
\hline $\mathrm{Zn}$ & NS & NS & 0.36 & NS & NS & NS & NS & 0.46 & 0.26 & 1 \\
\hline
\end{tabular}

OM, organic matter content; *, significant at $\alpha=0.05$; NS, not significant.

content was unlikely the dominant factor influencing nutrient availability during the sugarcane growing season.

Changes in soil pH can mobilize nutrients from unavailable phases to available pools. Studies have shown that soil $\mathrm{pH}$ affects crop nutrient availability (Wei et al., 2006). In the EAA, elemental S is applied as a soil amendment for the purpose of reducing $\mathrm{pH}$ and therefore increasing nutrient availability (Rice et al., 2006). Our results suggested that application of S up to $448 \mathrm{~kg} \mathrm{ha}^{-1}$ introduced limited effects on soil $\mathrm{pH}$ and therefore had little influence on enhancing nutrient availability. Statistical analysis revealed that $\mathrm{pH}$ was significantly correlated with acetic acid extractable Fe and $\mathrm{Zn}$ and Mehlich-3 extractable $\mathrm{Cu}$ and $\mathrm{Mn}$ (Tables 2 and 3). Nonetheless, no correlations were found between soil $\mathrm{pH}$ and any water-extractable nutrient concentrations (Table 4), which suggests that soluble nutrients were not as sensitive as adsorbed or complexed nutrients to small changes in soil $\mathrm{pH}$.

TABLE 4 Pearson correlation coefficients ( $\mathrm{r}$ ) between soil $\mathrm{pH}$, organic matter content, and concentrations of water-extractable nutrients $(n=64)$

\begin{tabular}{|c|c|c|c|c|c|c|c|c|c|c|}
\hline & $\mathrm{pH}$ & $\mathrm{OM}$ & $\mathrm{P}$ & $\mathrm{K}$ & $\mathrm{Ca}$ & $\mathrm{Mg}$ & $\mathrm{Cu}$ & $\mathrm{Fe}$ & $\mathrm{Mn}$ & $\mathrm{Zn}$ \\
\hline $\mathrm{pH}$ & 1 & & & & & & & & & \\
\hline $\mathrm{OM}$ & $-0.45^{*}$ & 1 & & & & & & & & \\
\hline $\mathrm{P}$ & -0.32 & NS & 1 & & & & & & & \\
\hline $\mathrm{K}$ & -0.56 & NS & 0.63 & 1 & 0 & & & & & \\
\hline $\mathrm{Ca}$ & -0.39 & NS & 0.42 & 0.90 & 1 & & & & & \\
\hline $\mathrm{Mg}$ & -0.42 & NS & 0.39 & 0.90 & 0.99 & 1 & & & & \\
\hline $\mathrm{Cu}$ & NS & NS & NS & NS & NS & NS & 1 & & & \\
\hline $\mathrm{Fe}$ & NS & NS & -0.26 & -0.74 & -0.86 & -0.86 & NS & 1 & & \\
\hline Mn & NS & NS & NS & -0.27 & -0.29 & -0.28 & 0.26 & NS & 1 & \\
\hline $\mathrm{Zn}$ & NS & NS & NS & NS & NS & NS & 0.54 & NS & 0.42 & 1 \\
\hline
\end{tabular}

OM, organic matter content; *, significant at $\alpha=0.05$; NS, not significant. 
Calcium carbonate is able to precipitate micronutrient ions in soil solution during the formation of carbonate depending on desorption characteristics of micronutrients and the solubility of carbonate (Wei et al., 2006). Phosphate can affect micronutrient availability by direct precipitation of nutrient cations. However, the effect varies among micronutrients and depends on other soil properties, such as water content (Li et al., 2007), pH (Wei et al., 2006) and metal solubility (Shuman, 1988), which helps to explain the varied relationships between $\mathrm{P}$ and micronutrient concentrations (Tables 2, 3, and 4) in this study. Correlation analysis revealed significantly negative correlations between water-extractable $\mathrm{Ca}$ and $\mathrm{Fe}\left(\mathrm{r}^{2}=-0.86\right)$ and $\mathrm{Mn}\left(\mathrm{r}^{2}=-0.29\right)$, indicating that the increasing $\mathrm{CaCO}_{3}$ content in these soils with ongoing subsidence will likely to decrease micronutrient availability in the future, making fertilizer management even more critical. Mehlich-3 extractable Ca was also significantly correlated to Mehlich-3 extractable Fe and $\mathrm{Mn}$, which may further suggest that $\mathrm{Fe}$ and $\mathrm{Mn}$ availability in these calcareous soils was affected by the $\mathrm{CaCO}_{3}$ content.

\section{Comparison of Soil Extractants}

Nutrients exist in soil as water soluble, exchangeable, and nonexchangeable forms. The contribution of these pools to nutrient availability to crops depends on the dynamic equilibrium among different pools. Therefore, different extraction methods reflect the degree of nutrient availability (Wright et al., 2007). Water extracts represent the readily available chemical forms, whereas acetic acid and Mehlich-3, are more acidic and extract the pools consisting of soluble, exchangeable, and some of non-exchangeable compounds (Cancela et al., 2002; Wright et al., 2007). Our results indicated that, as expected, acetic acid and Mehlich-3 extracted more P, K, Ca, Mg, $\mathrm{Mn}$, and $\mathrm{Zn}$ than water (Table 1).

Acetic acid and Mehlich-3 have been deemed satisfactory extractants for soil testing of EAA soils (Korndörfer et al., 1995; Hochmuth et al., 1996). Mehlich-3 solution contains large amounts of salts, strong acids, and ethylenediaminetetraacetic acid (EDTA). Salts are present mainly for extracting major cation such as $\mathrm{P}, \mathrm{K}, \mathrm{Ca}$, and $\mathrm{Mg}$, while micronutrient extraction is accomplished by metal-EDTA complexation (Wang et al., 2004). Nonetheless, compared to $0.5 \mathrm{~N}$ acetic acid, Mehlich-3 extracted equal amounts of $\mathrm{P}, \mathrm{K}$, and $\mathrm{Zn}$, but less $\mathrm{Ca}, \mathrm{Mg}, \mathrm{Mn}$, and Fe (Table 1), indicating that acidity may in fact control the $\mathrm{Ca}, \mathrm{Mg}, \mathrm{Mn}$, and $\mathrm{Fe}$ availability in this calcareous organic soil, as strong acidity can help to dissolve these cations from precipitates. Acetic acid is more acidic than Mehlich-3 and appeared less affected by soil buffering capacity and the presence of free $\mathrm{CaCO}_{3}$ (Korndörfer et al., 1995) and therefore extracted more $\mathrm{Ca}, \mathrm{Mg}$, $\mathrm{Mn}$, and Fe. In other words, acetic acid method tends to extract relatively high amounts of non-exchangeable nutrients and thus may overestimate the 
concentrations of available nutrients. Mehlich-3 extracted more $\mathrm{Cu}$ than acetic acid and water, suggesting that extractable $\mathrm{Cu}$ was likely present in a complex with organic matter rather than as an insoluble precipitate and EDTA in Mehlich-3 functioned to capture $\mathrm{Cu}$. In fact, $\mathrm{Cu}$ is often associated with dissolved organic matter (Wright et al., 2007).

\section{Nutrient Availability and Sugar Yield}

Sulfur amendment did increase the availability of $\mathrm{P}, \mathrm{K}$, and $\mathrm{Zn}$ at 2 months after application. Nonetheless, S application did not increase sugar yield. The yields for soils amended with $0,112,224$, and $448 \mathrm{~kg} \mathrm{~S}^{-1}$ averaged $16,17,16$, and $17 \mathrm{Mg}$ sugar ha ${ }^{-1}$, respectively. Results indicate that $\mathrm{S}$ application was not needed with the soil characteristics of the test field. Our results also indicated that $\mathrm{S}$ application is likely to increase the risk of $\mathrm{SO}_{4}$ export from fields. Large scale $\mathrm{S}$ application should be well evaluated, since $\mathrm{SO}_{4}$ export from the EAA into Everglades wetlands has been implicated in causing stimulation of $\mathrm{SO}_{4}$-reducing bacteria and $\mathrm{Hg}$ methylation (Gabriel et al., 2008). Nonetheless, it has been reported that actual grower $\mathrm{S}$ application rates in the EAA are lower than the current recommended rates (Schueneman, 2001), primarily due to economic costs associated with fertilizers and their application. Everglades Agricultural Area growers occasionally use micronutrient sprays to alleviate nutrient deficiency caused by elevated $\mathrm{pH}$ since a short-term benefit can be achieved at relatively low cost, so $\mathrm{S}$ application may not be considered necessary in many EAA fields at this stage. However, site-specific precise applications may become necessary in the future to provide a nutrient supply at planting.

Significant linear regression equations for prediction of sugar yields with extractable nutrients are listed in Table 5. Stepwise multiple regressions identified the most significant model considering Mehlich-3 extractable $\mathrm{P}$ prior to planting as the main predictor, which explains $93 \%$ of the variation in sugar yield. Regression equations for 2, 6, and 9 months had low coefficients of determinations ranging from 0.30 to 0.60 , suggesting important factors influencing sugar yield were not quantified (Anderson et al., 1999).

TABLE 5 Multiple regression models relating soil nutrient concentrations $\left(\mathrm{mg} \mathrm{kg}^{-1}\right)$ with sugar yield $\left(\mathrm{Mg} \mathrm{ha}^{-1}\right)$ at different times during the growing season

\begin{tabular}{llr}
\hline Time (months) & \multicolumn{1}{c}{ Equation } & $\mathrm{R}^{2}$ \\
\hline 0 & $\mathrm{Y}=57-1.42(\mathrm{M}-\mathrm{P})$ & 0.93 \\
2 & $\mathrm{Y}=20-0.04(\mathrm{~W}-\mathrm{Mg})+0.01\left(\mathrm{~W}-\mathrm{SO}_{4}\right)$ & 0.52 \\
6 & $\mathrm{Y}=21-54.06(\mathrm{~W}-\mathrm{Mn})$ & 0.30 \\
9 & $\mathrm{Y}=14-0.04(\mathrm{~A}-\mathrm{K})+0.17(\mathrm{~W}-\mathrm{K})$ & 0.60 \\
13 & $\left.\mathrm{Y}=10+0.13(\mathrm{NO})_{3}-\mathrm{N}\right)+15.09(\mathrm{~W}-\mathrm{Mn})-1.06(\mathrm{~W}-\mathrm{P})$ & 0.81 \\
\hline
\end{tabular}

Y, sugar yield; M, Mehlich-3 extractable nutrient; W, water extractable nutrient; A, acetic acid extractable nutrient. 
Meanwhile, the response of sugar yield to a specific factor may not be linear. General linear models only offered rough approximations of the relationships and therefore may not be adequate in this case (Korndörfer et al., 1995; Anderson et al., 1999).

\section{CONCLUSIONS}

Sulfur application at rates up to $448 \mathrm{~kg} \mathrm{ha}^{-1}$ had limited effects on the reduction in soil $\mathrm{pH}$ due to the high soil buffering capacities and generally failed to enhance nutrient availability. Correspondingly, S application at current recommendation rates did not increase sugar yield at a location with an unamended $\mathrm{pH}<7.0$. Sulfur application increased $\mathrm{SO}_{4}$ concentrations in soils and also the risk for export from fields. Therefore, large scale of $\mathrm{S}$ application should be evaluated for their potential to adversely affect proximal sensitive wetland ecosystems. Alternatives, such as different $\mathrm{P}$ and micronutrient fertilizer application methods, timings, and sources, may be better for increasing nutrient availability for these changing soils.

\section{REFERENCES}

Anderson, D. L. 1985. Crop soil fertility recommendations of the Everglades soil testing laboratory. EREC-Belle Glade Report EV-1985-10. Belle Glade, FL: University of Florida.

Anderson, D. L., K. N. Portier, T. A. Obreza, M. E. Collins, and D. J. Pitts. 1999. Tree regression analysis to determine effects of soil variability on sugarcane yields. Soil Science Society of America Journal 63: 592-600.

Beverly, R. B., and D. Anderson. 1986. Effects of acid source on soil pH. Soil Science 143: 301-303.

Cancela, R. C., C. A. de Abreu, and A. Paz-González. 2002. DTPA and Mehlich-3 micronutrient extractability in natural soils. Communications in Soil Science and Plant Analysis 33: 2879-2893.

Castillo, M. S., and A. L. Wright. 2008. Soil phosphorus pools for Histosols under sugarcane and pasture in the Everglades, USA. Geoderma 145: 130-135.

Codling, E. E. 2008. Effects of soil acidity and cropping on solubility of by-product-immobilized phosphorus and extractable aluminum, calcium, and iron from two high-phosphorus soils. Soil Science 173: 552-559.

Deubel, A., H. Braune, H. Tanneberg, and W. Merbach. 2007. Conversion and acidifying effect of elemental sulphur in an alkaline loess soil. Archives of Agronomy and Soil Science 53: 161-171.

Gabriel, M., G. Redfield, and D. Rumbold. 2008. Sulfur as a regional water quality concern in south Florida. South Florida Environmental Report, Appendix 3B-2. West Palm Beach, FL: South Florida Water Management District.

Gharmakher, H. N., J. M. Machet, N. Beaudoin, and S. Recous. 2009. Estimation of sulfur mineralization and relationships with nitrogen and carbon in soils. Biology $\mathcal{E}^{\mathcal{O}}$ Fertility of Soils 45: 297-304.

Gilbert, R. A., and R. W. Rice. 2006. Nutrient requirements for sugarcane production on Florida muck soils. UF-IFAS SS-AGR-226. Gainesville, FL: University of Florida.

Glaz, B., S. J. Edme, J. D. Miller, S. B. Milligan, and D. G. Holder. 2002. Sugarcane cultivar response to high summer water tables in the Everglades. Agronomy Journal 94: 624-629

Hassan, N., and R. A. Olson. 1966. Influence of applied sulfur on availability of soil nutrients for corn (Zea mays L.) nutrition. Soil Science Society of America Journal 30: 284-286.

Heitholt, J. J., J. J. Sloan, and C. T. MacKown. 2002. Copper, manganese, and zinc fertilization effects on growth of soybean on a calcareous soil. Journal of Plant Nutrition 25: 1727-1740.

Herencia, J. F., J.C. Ruiz, E. Morillo, S. Melero, J. Villaverde, and C. Maqueda. 2008. The effect of organic and mineral fertilization on micronutrient availability in soil. Soil Science 173: 69-80. 
Hochmuth, G., E. A. Hanlon, G. H. Snyder, R. T. Nagata, and T. Schueneman. 1996. Fertilization of sweet corn, celery, romaine, escarole, endive, and radish on organic soils in Florida. UF-IFAS BUL-313. Gainesville, FL: University of Florida.

Jaggi, R. C., M. S. Aulakh, and A. R. Sharma. 2005. Impacts of elemental S applied under various temperature and moisture regimes on $\mathrm{pH}$ and available $\mathrm{P}$ in acidic, neutral and alkaline soils. Biology and Fertility of Soils 41: 52-58.

Korndörfer, G. H., D. L. Anderson, K. M. Portier, and E. A. Hanlon. 1995. Phosphorus soil test correlation to sugarcane grown on Histosols in the Everglades. Soil Science Society of America Journal 59: 1655-1661.

Kuo, S. 1996. Phosphorus. In: Methods of Soil Analysis, Part 3, ed. D. L. Sparks, pp. 869-919. Madison, WI: SSSA.

Li, B. Y., D. M. Zhou, L. Cang, H. L. Zhang, X. H. Fan, and S. W. Qin. 2007. Soil micronutrient availability to crops as affected by long-term inorganic and organic fertilizer applications. Soil and Tillage Research 96: 166-173.

Majchrzak, R. N., K. R. Olson, G. Bollero, and E. D. Nafziger. 2001. Using soil properties to predict wheat yields on Illinois soils. Soil Science 166:267-280.

Moral, R., J. Moreno-Caselles, M. Perez-Murcia, and A. Perez-Espinosa. 2002. Improving the micronutrient availability in calcareous soils by sewage sludge amendment. Communications in Soil Science and Plant Analysis 33: 3015-3022.

Moreno-Caselles, J., R. Moral, M. D. Perez-Murcia, A. Perez-Espinosa, C. Paredes, and E. Agulló. 2005. $\mathrm{Fe}, \mathrm{Cu}, \mathrm{Mn}$, and $\mathrm{Zn}$ input and availability in calcareous soils amended with the solid phase of pig slurry. Communications in Soil Science and Plant Analysis 36: 525-534.

Morgan, K. T., J. M. McCray, R. W. Rice, R. A. Gilbert, and L. E. Baucum. 2009. Review of current sugarcane fertilizer recommendations: A report from the UF/IFAS sugarcane fertilizer standards task force. UF EDIS SL 295. Gainesville, FL: University of Florida.

Mylavarapu, R. S. 2009. UF/IFAS extension soil testing laboratory (ESTL) analytical procedures and training manual. UF Circular 1248 Gainesville, FL: University of Florida.

Parsons, K. J., V. D. Zheljazkov, J. MacLeod, and C. D. Caldwell. 2007. Soil and tissue phosphorus, potassium, calcium, and sulfur as affected by dairy manure application in a no-till corn, wheat, and soybean rotation. Agronomy Journal 99: 1306-1316.

Provin, T. L., A. L. Wright, F. M. Hons, D. A. Zuberer, and R. H. White. 2008. Seasonal dynamics of soil micronutrients in compost-amended bermudagrass turf. Bioresource Technology 99: 2672-2679.

Rice, R. W., R. A. Gilbert, and R. S. Lentini. 2006. Nutrient requirements for Florida sugarcane. UF-IFAS SS-AGR-228 Gainesville, FL: University of Florida.

Rogovska, N. P., A. M. Blackmer, and A. P. Mallarino. 2007. Relationships between soybean yield, soil $\mathrm{pH}$, and soil carbonate concentration. Soil Science Society of America Journal 71: 1251-1256.

Schueneman, T. J. 2001. Characterization of sulfur sources in the EAA. Soil and Crop Science Society of Florida Proceedings 60: 49-52.

Shih, S. F., B. Glaz, and R. E. Barnes. 1998. Subsidence of organic soils in the Everglades Agricultural Area during the past 19 years. Soil and Crop Science Society of Florida Proceedings 57: 20-29.

Shuman, L. M. 1988. Effect of phosphorus level on extractable micronutrients and their distribution among soil fractions. Soil Science Society of America Journal 52: 136-141.

Slaton, N. A., B. R. Golden, R. J. Norman, C. E. Wilson, and R. E. DeLong. 2009. Correlation and calibration of soil potassium availability with rice yield and nutrimental status. Soil Science Society of America Journal 73: 1192-1201.

Snyder, G. H. 2005. Everglades Agricultural Area soil subsidence and land use projections. Soil and Crop Science Society of Florida Proceedings 64: 44-51.

Strahm, B. D., and R. B. Harrison. 2007. Mineral and organic matter controls on the sorption of macronutrient anions in variable-charge soils. Soil Science Society of America Journal 71: 1926-1933.

Wang, J. J, D. L. Harrell, R. E. Henderson, and P. F. Bell. 2004. Comparison of soil-test extractants for phosphorus, potassium, calcium, magnesium, sodium, zinc, copper, manganese, and iron in Louisiana soils. Communications in Soil Science and Plant Analysis 35: 145-160.

Wei, X., M. Hao, M. Shao, and W. J. Gale. 2006. Changes in soil properties and the availability of soil micronutrients after 18 years of cropping and fertilization. Soil Eं Tillage Research 91: 120-130.

Wright, A. L. 2009. Soil phosphorus stocks and distribution in chemical fractions for long-term sugarcane, pasture, turfgrass, and forest systems in Florida. Nutrient Cycling in Agroecosystems 83: 223-231. 
Wright, A. L, T. L. Provin, F. M. Hons, D. A. Zuberer, and R. H. White. 2007. Soil micronutrient availability after compost addition to St. Augustinegrass. Compost Science Eं Utilization 15: 127-134.

Wright, A. L., Y. Wang, and K. R. Reddy. 2008. Loss-on-ignition method to assess soil organic carbon in calcareous Everglades wetlands. Communications in Soil Science and Plant Analysis 39: 3074-3083.

Ye, R., A. L. Wright, K. Inglett, Y. Wang, A. V. Ogram, and K. R. Reddy. 2009. Land use effects on soil nutrient cycling and microbial community dynamics in the Everglades Agricultural Area, Florida. Communications in Soil Science and Plant Analysis 40: 2725-2742.

Ye, R., A. L. Wright, J. M. McCray, K. R. Reddy, and L. Young. 2010. Sulfur-induced changes in phosphorus distribution in Everglades Agricultural Area soils. Nutrient Cycling in Agroecosystems 87: 127-135. 